6. Шейко В. Культура та глобалізація: компаративістський аналіз. URL: https://www.culturology.academy/wp-content/uploads/KD1_Sheiko. pdf (дата звернення 30.06.2021).

DOI https://doi.org/10.30525/978-9934-26-117-6-26

\title{
НАПРЯМИ ДОСЛІДЖЕНЬ УКРАЇНСЬКИХ МОЛОДИХ НАУКОВЦІВ: СПРОБА УЗАГАЛЬНЕННЯ НА МАТЕРІАЛАХ ЩОРІЧНОЇ МИСТЕЦТВОЗНАВЧО-РЕСТАВРАЦІЙНОЇ КОНФЕРЕНЦІЇ В НАОМА
}

\author{
Пітеніна В. $\mathbf{\epsilon}$. \\ викладач кафедри мистецтв та дизайну \\ Відокремлений структурний підрозділ «Фаховий коледж мистецтв та \\ дизайну Київського національного університету \\ технології та дизайну» \\ Стрельцова М. В. \\ старший науковий співробітник \\ Філія Національного музею «Київська картинна галерея» \\ Мистеиький иентр «Шоколадний будинок» \\ м. Київ, Україна
}

У контексті європейського напряму розвитку України актуальним $є$ питання: які теми найбільше цікавлять науковців у дослідженні істоpiї і теорії мистецтва. Українське мистецтвознавство історично було частиною радянського дискурсу. Тим часом, європейська спрямованість актуалізує дещо інші контексти. Користуючись матеріалами щорічної конференції «Платонівські читання», яка відбувається у Національній академії образотворчого мистецтва i архітектури (далі- НАОМА) 32014 року, ми спробували окреслити коло актуальних для молодих науковців питань, яке сформувалося за цих суперечливих умов.

НАОМА є одним із найстаріших профільних закладів України. Академія була створена 1917 року зусиллями художників В. Кричевського, Ф. Кричевського, В. Меллера, М. Бойчука, О. Мурашка, Г. Нарбута, М. Бурачека, М. Жука, А. Маневича [2, с. 14]. Основними ініціаторами створення Академії поряд із визначними художниками були історики мистецтва Д. Антонович, М. Біляшівський, 
Г. Павлуцький, а у 1959 році було засновано факультет теорії та історії мистецтва, який очолив П. Говдя.

Конференцію «Платонівські читання» ініціювала 2002 року професор Л. С. Міляєва в пам'ять про видатного історика мистецтва, професора Платона Олександровича Білецького. Незмінним координатором проекту, упорядником текстів та збірки тез є кандидат мистецтвознавства Л. О. Лисенко. Коло наукових інтересів П. Білецького охоплювало обшир проблем: від мистецтва Китаю до творчості Г. Нарбута. Діапазон тем, які досліджував науковець, обумовив і розгорнуту тематику конференції - від історії українського мистецтва до педагогічно-реставраційної проблематики та питань мистецтва Свропи та Сходу. Це дало змогу брати участь у конференції студентам, аспірантам, науковцям із різних регіонів. Географічне охоплення конференції значне: у 2020 році 99 учасників з Києва, 23 - зі Львова, 5- 3 Одеси, 14 - із Харкова, 2 - $з$ Івано-Франківська, 2 із Кам'янця-Подільского, 4- з Коростишева, 6- з Китаю. Рівень кваліфікації науковців також неоднорідний: у 2020 в конференції взяли участь 32 кандидати наук, 43 аспіранти, 28 бакалаврів і магістрів iз Києва, Львова, Одеси, Харкова.

Доповіді розподілено на три секції: «Проблеми вивчення українського мистецтва від давнини до початку XX ст.» (1), «Проблеми вивчення українського мистецтва XX-XXI століття; методика викладання профільних дисциплін у вищих мистецьких закладах; проблеми сучасної художньої освіти» (2), «Класичне і сучасне мистецтво Заходу та Сходу» (3).

\begin{tabular}{|c|c|c|c|c|c|c|}
\hline Рік / секція & $\mathbf{2 0 2 0}$ & $\mathbf{2 0 1 9}$ & $\mathbf{2 0 1 8}$ & $\mathbf{2 0 1 7}$ & $\mathbf{2 0 1 6}$ & $\mathbf{2 0 1 5}$ \\
\hline 1 & 33 & 35 & 40 & 24 & 20 & 13 \\
\hline 2 & 90 & 90 & 99 & 81 & 59 & 44 \\
\hline 3 & 29 & 31 & 28 & 24 & 27 & 7 \\
\hline
\end{tabular}

Статистичні відомості таблиці щодо тематичного розподілу учасників дозволяють зробити деякі висновки. Більшість тем актуальних досліджень останніх шести років стосується саме мистецтва України XX століття та педагогічної практики викладання. Майже однакову кількість праць присвятили науковці мистецтву України від давнини до ХХ століття і мистецтву західної Свропи та Сходу.

Аналізуючи тематичне охоплення, зазначимо, що тема європейського та східного мистецтва цікавить здебільшого дослідниківмузейників. У доповідях висвітлено та представлено науковому загалу дослідження музейних колекцій та методи їхнього експонування. Теми 
охопили широке коло об'єктів - від меморіальної скульптури XVI - XVII ст. (А. Легезда), експонатів музею-заповідника «Підгорецький замок» (І. Чехут), творчості М. Сельської (М. Максимів), польських художників Я. Станіславського (С. Стець) та Я. Мальчевського (О. Калініченко) до знакової колекції пейзажних творів західноi східноєвропейських майстрів (І. Шабля). Це $\epsilon$ важливим кроком для ознайомлення 3 робочими гіпотезами та попередніми висновкам i сприяє подальшому поглибленню міждисциплінарних та культурологічних досліджень.

Вагому частку досліджень мистецтва Сходу і Заходу складають розвідки про мистецтво Китаю, що також базуються на музейних колекціях Києва і Одеси (М. Логвин, Д. Марков, В. Вершинін, О. Новікова) або на матеріалах, доступних студентам із Китаю, які навчаються в Україні (Ван Мінь, Лю Фань, Цю Чжуанюй, Лай Юеге). У 2020 році тематика огляду європейського мистецтва розширилась за рахунок окремих публікацій про мистецький образ Норвегії (О. Сом-Сердюкова), принципів войовничості в еллінізмі (А. Пучков), атрибуцій північно-європейського живопису XV століття (Р. Лубинський). Вкрай важливими, але нечисленними є міждисциплінарні теми та пошук стилістичних та формальних аналогій (О. Буднікова, О. Сом-Сердюкова, А. Кретов, В. Чечик, А. Пучков, Л. Лисенко).

Водночас, треба визнати, що дослідження європейських колекцій не входить у коло тем, актуальних для молодих українських науковців, представлених на конференції. При широкому обсязі тем майже відсутні публікації високого рівня узагальнення, а більшість матеріалів присвячено вивченню матеріалу з українських музейних або приватних колекцій.

У доповідях про українське мистецтво від давнини до кінця XIX століття значну частину (10 із 33 у 2020 році, 10 із 35 у 2019, 6 із 40 у 2018, 7 із 24 у 2017) складають реставраційні дослідження. Питання збереження та реставрації пам'яток вкрай актуальне, особливо в контексті недостатньої регуляції охорони пам'яток. У 2020 році дотично до теми реставрації пам'яток у доповіді професора Л. С. Міляєвої прозвучали питання професійної етики реставратора. Питання атрибуції та реставрації іконопису (матеріали О. Віслободова, О. Садової-Мандюк, І. Сомик-Пономаренко, О. Рішняка, Я. Дерези, Д. Жигалкіна, О. Калиновської, Т. Тимченко, О. Рижової, В. Распопіної) тісно пов'язані з проблемами іконографії, яким присвятили доповіді О. Широка, О. Шевлюга, А. Авула. 
Тим часом такі історичні аспекти, як книжкова гравюра, шрифти, висвітлені в окремих доповідях (І. Дудник, Є. Зігура), поступаються кількістю дослідженням іконопису та іконографії.

Найбільшу увагу мистецтвознавців, істориків і культурологів, залучених до конференції, привертає XX століття. Безперечно, саме цей період має найбільше коло невисвітлених раніше питань, які надають змогу молодим і досвідченим науковцям працювати із новим або неопублікованим раніше матеріалом. Коло порушених проблем українського мистецтва XX століття - від атрибуції доробку репресованих майстрів та аналізу періоду авангарду (О. Лагутенко, I. Прокопчук, О. Боримська, О. Соколюк, О. Тарасенко) до сучасної практики мистецтва (М. Стрельцова, Ю. Катеринчук, Н. Булавіна) та його викладання (Ю. Богатова, М. Селівачов, Ю. Майстренко-Вакуленко, Г. Андрес, Л. Басанець). Активний інтерес викликає радянська спадщина, яку описано лише частково. Великі масиви опублікованого раніше матеріалу потребують переосмислення, що відображено в доповідях М. Кокшайкіна, В. Григорова, І. Балтазюка, Г. Хорунжої, К. Маркарової, Т. Павлової, Н. Корчиної. Невелика кількість доповідей стосується української книжкової графіки, зокрема перших десятиріч XX століття (Ю. Каменецька, П. Малинка, І. Дуднік), та архітектури (М. Астанін, Т. Коломоєць). Фрагментарно висвітлено сучасну симпозіумну експозиційну практику (М. Стрельцова) та роботу із сучасними медіа (О. Щербатюк). Поодинокі міждисциплінарні розвідки з'явилися лише у 2019-2020 роках (К. Шиман, І. Адамська), але, на нашу думку, таких досліджень надалі більшатиме.

3 огляду на зазначене вище можна дійти висновку, що увага науковців, які беруть участь у конференції, зосереджена здебільшого на $\mathrm{XX}$ столітті. У зв'язку з появою нових матеріалів, відкриттям архівів та спробами переосмислення цього періоду на часі - дослідження радянського мистецтва. Великі «білі плями» у вивченні саме мистецтва України XX століття роблять первинні дослідження матеріалів цього періоду найактуальнішими. Провідними темами залишаються дослідження іконографії та реставрації українського мистецтва XVII-XIX століть та музейних колекцій. Утім, розвідок у галузі сучасного мистецтва, практики експонування, міждисциплінарних досліджень сучасних медіа - наразі недостатньо.

\section{Література:}

1. Восьмі Платонівські читання. Тези доповідей Міжнародної наукової конференції. Київ: СПД Чалчинська Н. В., 2021. 
2. Кошуба-Вольвач О. Українська академія мистецтв: історія заснування та фундатори. Київ: Родовід, 2015

3. П'яті платонівські читання. Тези доповідей міжнародної наукової конференції. Київ: Видавництво Людмила, 2019.

4. Сьомі Платонівські читання. До 60-річчя кафедри ТIM і 50-річчя кафедри ТРТМ НАОМА. Тези доповідей Міжнародної наукової конференції. Київ: Видавництво Людмила, 2020.

5. Четверті платонівські читання. Тези доповідей міжнародної наукової конференції. Київ: СПД Чалчинська, 2017.

6. Шості платонівські читання. До сторіччя НАОМА. Тези доповідей міжнародної наукової конференції. Київ: Видавництво Людмила, 2019.

\title{
DOI https://doi.org/10.30525/978-9934-26-117-6-27
}

\section{ОБІГ ТВОРІВ МИСТЕЦТВА ЯК СФЕРА КУЛЬТУРОЛОГІЧНИХ ДОСЛІДЖЕНЬ}

\author{
Русаков С. C. \\ кандидат філософських наук, дочент, \\ докторант кафедри культурології та інформачійних комунікацій \\ Національна академія керівних кадрів культури і мистецтв \\ м. Київ, Украӥна
}

Мистецтво є важливою складовою людської культури, тому постійно аналізується у культурологічних та мистецтвознавчих дослідженнях, а також у філософських, соціологічних та економічних наукових розвідках. Особливості моделей обігу творів мистецтва заслуговують детального вивчення, адже вони $є$ відображенням процесів, які впливають на динаміку культури.

Серед вітчизняних напрацювань бракує наукових розвідок про обіг творів мистецтва, адже здебільшого заведено зосереджуватись на описі життєтворчості знакових митців, інтерпретації їхніх творів й стилів, виокремленні найкращих творів певної епохи. На нашу думку, такий підхід вдало розвиває мистецтвознавчі дослідження, проте в рамках культурологічних студій потрібно також виокремити вивчення обігу творів, що допоможе глибшому розумінню ціннісних орієнтацій у різні періоди, в тому числі сьогоденні. 